\title{
Analisis dan Perancangan Sistem Informasi Rekam Medis Puskesmas Jatilawang
}

\author{
Ginanjar Ramadhan ${ }^{1}$, Rinda Hesti Kusumaningtyas ${ }^{2}$
}

\begin{abstract}
Abstrak-Bidang kesehatan yang semakin hari semakin kompleks, membuat fasilitas kesehatan menerapkan teknologi informasi demi mendukung kinerjanya. Salah satu teknologi informasi yang bisa diterapkan adalah kegiatan rekam medis. Namun, Puskesmas Jatilawang belum menerapkan sistem informasi rekam medis dengan baik. Rekam medis yang berjalan masih menggunakan rekam medis manual atau menggunakan kertas yang memiliki beberapa kelemahan seperti sulitnya ditransfer antar poliklinik, lambatnya proses klaim BPJS, dan mudah hilang, tercecer, serta salah letak. Berdasarkan permasalahan tersebut, maka penulis melakukan kegiatan Analisis dan Perancangan Sistem Informasi Rekam Medis Puskesmas Jatilawang. Analisis dan perancangan sistem ini dibuat menggunakan object oriented dengan pendekatan Rapid Application Development (RAD) dan menggunakan Unifed Modelling Langunge (UML) sebagai alat bantu pendeskripsian dan perancangan sistem. Dengan adanya analisis dan perancangan sistem ini, dapat menjadi sistem usulan dan dapat diterapkan oleh Puskesmas Jatilawang untuk mempermudah kegiatan rekam medis pasien sehingga menjadi akurat, cepat, dan efisien.
\end{abstract}

\section{Kata Kunci-Puskesmas, Rekam Medis, RAD, UML.}

P

\section{Pendahuluan}

Kesehatan Masyarakat (Puskesmas) adalah fasilitas pelayanan kesehatan yang menyelenggarakan upaya kesehatan masyarakat dan upaya kesehatan perseorangan tingkat pertama, dengan lebih mengutamakan upaya promotif dan preventif, untuk mencapai derajat kesehatan masyarakat yang setinggi-tingginya di wilayah kerjanya. Puskesmas merupakan salah satu instansi yang mewajibkan penggunaan sistem informasi baik diselenggarakan secara elektronik maupun non elektronik [1].

Tantangan pembangunan kesehatan menuntut adanya dukungan sumber daya yang cukup, serta arah kebijakan dan strategi pembangunan kesehatan yang tepat. Namun, sering kali para pembuat kebijakan di bidang kesehatan mengalami kesulitan dalam hal pengambilan keputusan yang tepat karena keterbatasan atau ketiak sediaan data dan informasi yang akurat, tepat, dan cepat. Data dan informasi merupakan sumber daya yang sangat strategis dalam pengelolaan pembangunan

Received: 10 Januari 2019; Revised: 15 Maret 2019; Accepted: 1 April 2019

G. Ramadhan, UI/UX Designer, Tribelio Jakarta, Indonesia (e-mail: ginanjaramadhan@gmail.com)

R. H. Kusumaningtiyas, Prodi Sistem Informasi, UIN Syarif Hidayatullah Jakarta, Indonesia (e-mail: rinda.hesti@uinjkt.ac.id) kesehatan, yaitu pada proses manajemen, pengambilan keputusan, kepemerintahan, dan penerapan akuntabilitas [2].

Sistem Informasi Rekam Medis adalah rekam medik berbasis komputer atau gudang penyimpanan informasi secara elektronik mengenai status kesehatan dan layanan kesehatan yang diperoleh pasien sepanjang hidupnya, tersimpan sedemikian hingga dapat melayani berbagai pengguna rekam yang sah [3]. Penggunaan komputer sebagai sarana pendukung kegiatan manusia dalam melakukan aktivitas menjadi salah satu bukti perkembangan teknologi. Hampir di setiap perusahaan mengaplikasikan penggunaan komputer sebagai alat pendukung dalam pekerjaan yang dilakukan, hal tersebut juga dilakukan oleh industri jasa, salah satu contohnya adalah rumah sakit dan puskesmas. Penggunaan komputer ini membuat peran pengguna menjadi penting karena merekalah yang memakai langsung pekerjaannya [4].

Pencatatan rekam medis yang manual di atas kertas sangat sulit untuk ditransfer antar rumah sakit apalagi pada kondisi geografis Indonesia dengan bentuk negeri seribu pulau. Masalah transportasi menjadi permasalahan yang bisa menghambat pertukaran informasi riwayat kesehatan pasien [5].

Pencatatan rekam medis manual tidak selalu tersimpan dalam rak penyimpanan. Ada kalanya rekam medis tersebut berada di bagian assembling, coding, indexing, di klinik atau di bangsal. Proses pencarian rekam medis manual memerlukan waktu yang lama, karena tidak selalu terdapat dalam rak penyimpanan. Dalam melakukan proses pemberkasan menggunakan sumber daya manusia terkait dalam proses pemberkasan yaitu petugas pemberkasan. Petugas pemberkasan terkadang sulit mencari rekam medis yang tidak terdapat dalam rak penyimpanan, sehingga petugas pemberkasan harus mencari di mana rekam medis tersebut. Ketidaklengkapan pengisian rekam medis yang dilakukan oleh tenaga medis menyebabkan proses pemberkasan klaim terhadap BPJS terhambat [6].

Dengan sistem rekam medis digital akan efektif yaitu lebih tepat guna dan diharapkan dapat memenuhi kebutuhan secara tepat dan tepat. Secara digital/elektronik kegiatan ini lebih efektif karena manajemen waktu akan lebih baik terutama dalam pelayanan kesehatan kepada pengguna dan pasien. Hal ini senada dengan Undang-Undang Nomor 11 Tahun 2008 tentang Informasi dan Transaksi Elektronik pasal 4, pemanfaatan teknologi informasi dan transaksi elektronik dilaksanakan dengan tujuan untuk meningkatkan efektivitas dan efisiensi pelayanan publik [7]. 
Fleksibilitas rekam medis kertas sulit digunakan untuk kebutuhan yang berbeda. Rekam medis kertas harus dibawa dari tempat yang satu ke tempat yang lain yang akan dituju. Rekam medis terhubung dengan berbagai pihak, sehingga rekam medis mudah hilang, tercecer, dan salah letak. Meningkatnya permintaan beragam jenis informasi yang semakin tidak dapat terlaksana dengan cepat dan benar bila tetap menggunakan format bentuk fisik yang terbuat dari kertas [8].

\section{KAJIAN PENELITIAN}

\section{A. Sistem Informasi}

Sistem informasi adalah sistem di dalam organisasi yang mempertemukan kebutuhan pengelolaan transaksi harian, mendukung operasi, bersifat manajerial, dan kegiatan strategi dari organisasi dan menyediakan pihak luar tertentu dengan laporan-laporan yang dibutuhkan [9].

\section{B. Rekam Medis}

Rekam medis adalah catatan riwayat penyakit pada pasien. Beberapa catatan yang termasuk dalam data rekam medis adalah segala data tentang riwayat penyakit, hasil pemeriksaan fisik, diagnosis, pengobatan serta hasilnya, laporan dokter, perawat, hasil pemeriksaan laboratorium, ronsen, dan lain-lain. Data ini merupakan data yang bersifat rahasia sehingga tidak dapat dibuka oleh pihak ketiga tanpa izin dari pasien yang bersangkutan kecuali jika ada alasan lain berdasarkan peraturan atau perundang-undangan yang memaksa dibukanya informasi tersebut [10].

C. Rapid Application Development (RAD)

Rapid Application Development (RAD) adalah strategi siklus hidup yang ditujukan untuk menyediakan pengembangan yang jauh lebih cepat dan mendapatkan hasil dengan kualitas yang lebih baik dibandingkan dengan hasil yang dicapai melalui siklus tradisional [11]. RAD merupakan gabungan dari bermacam-macam teknik terstruktur dengan teknik prototyping dan teknik pengembangan joint application untuk mempercepat pengembangan sistem/aplikasi [12]. Dari definisi-definisi konsep RAD ini, dapat dilihat bahwa pengembangan aplikasi dengan menggunakan metode RAD ini dapat dilakukan dalam waktu yang relatif lebih cepat.

\section{Unified Modelling Language (UML)}

UML adalah himpunan struktur dan teknik untuk pemodelan dan desain object oriented programming (OOP) serta aplikasinya. UML adalah metodologi untuk mengembangkan sistem OOP dan sekelompok tool untuk medukung pengembangan sistem tersebut [13].

\section{Metode Penelitian}

Bagian ini menjelaskan kerangka penelitian yang ditunjukkan oleh gambar 1. Adapun penelitian ini dilakukan dalam 3 tahapan, (1) permulaan pelaksanaan penelitian, (2) melakukan pengumpulan data, dan (3) pengembangan sistem. Tahapan ketiga ini melakukan perencanaan syarat dan desain dengan membuat use case diagram, activity diagram, dan sequence diagram menggunakan UML, dilanjutkan dengan merancang database dan perancangan interface menggunakan aplikasi MockingBot.

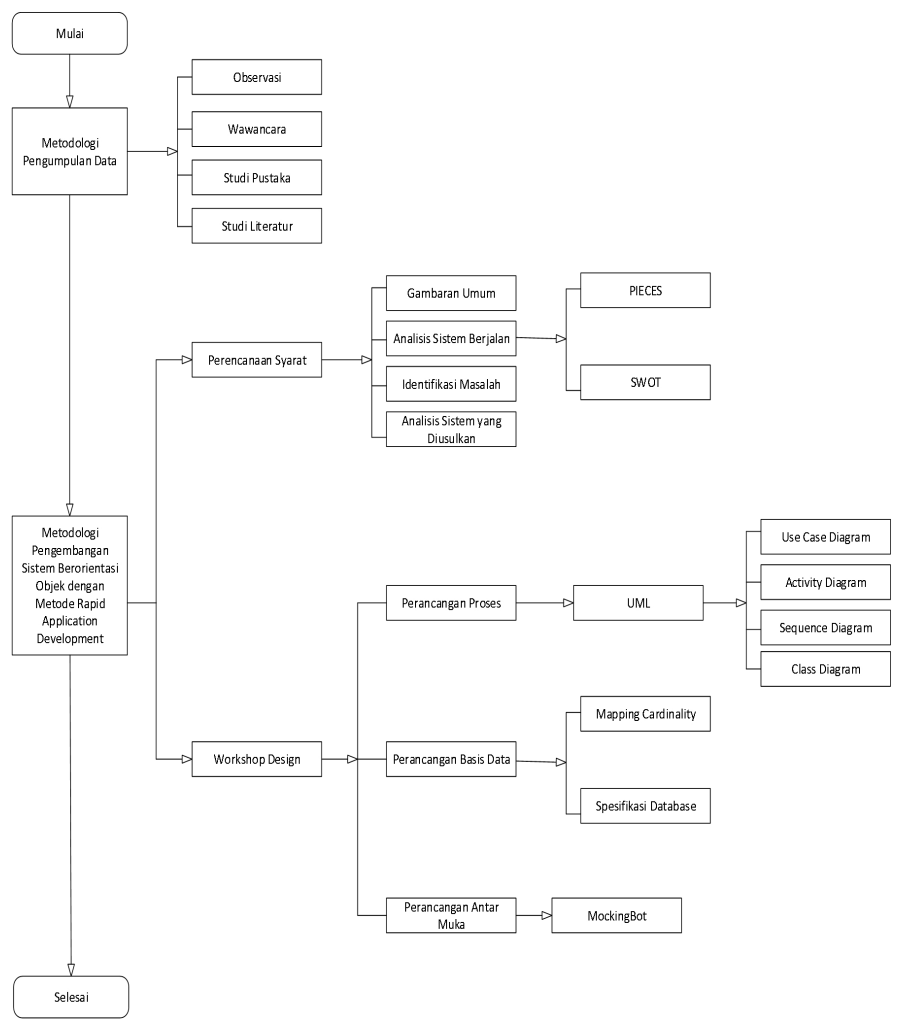

Gambar 1. Kerangka Penelitian

\section{PEMBAHASAN}

\section{A. Perencanaan Syarat \\ 1) Analisis Sistem Berjalan}




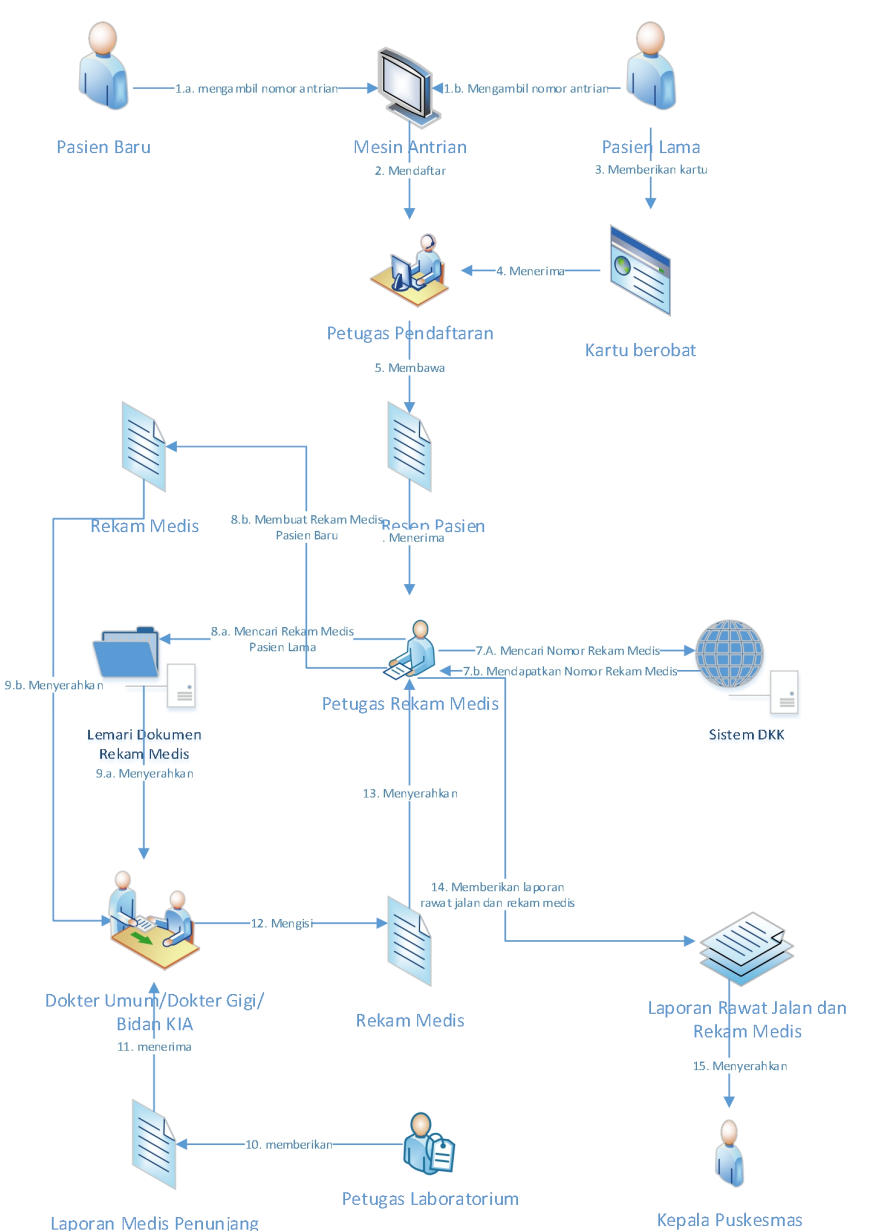

Gambar 2. Sistem Berjalan

Sistem berjalan pada gambar 2 merupakan hasil analisis berdasarkan observasi pada Puskesmas Jatilawang.

\section{a. Analisis PIECES}

Tabel 1.

Analisis PIECES

\begin{tabular}{|c|c|c|c|}
\hline No & Analisis & $\begin{array}{l}\text { Kelemahan Sistem } \\
\text { Lama }\end{array}$ & Sistem yang Diusulkan \\
\hline 1 & $\begin{array}{l}\text { Perfomance } \\
\text { (Kinerja) }\end{array}$ & $\begin{array}{l}\text { Rekam medis } \\
\text { manual masih } \\
\text { menggunakan } \\
\text { kertas, sehingga } \\
\text { tidak ada integrasi } \\
\text { antar bagian di } \\
\text { Puskesmas yang } \\
\text { memakan waktu } \\
\text { ketika harus } \\
\text { memindahkan rekam } \\
\text { medis dari bagian ke } \\
\text { bagian yang lain }\end{array}$ & $\begin{array}{lr}\text { Sistem informasi } \\
\text { rekam medis yang } \\
\text { diusulkan } & \text { akan } \\
\text { menghubungkan antar } \\
\text { bagian di Puskesmas, } \\
\text { sehingga } \\
\text { terintegrasi }\end{array}$ \\
\hline 2 & $\begin{array}{l}\text { Information } \\
\text { (Informasi) }\end{array}$ & $\begin{array}{l}\text { Alur informasi yang } \\
\text { ada di Puskesmas } \\
\text { masih bersifat } \\
\text { manual, dan sering } \\
\text { terjadi human error } \\
\text { dikarenakan } \\
\text { penulisan yang tidak }\end{array}$ & $\begin{array}{l}\text { Pada sistem yang } \\
\text { diusulkan akan sedikit } \\
\text { mengurangi human } \\
\text { error karena akan } \\
\text { tersistem. Pelaporan } \\
\text { akan menjadi cepat } \\
\text { karena langsung }\end{array}$ \\
\hline
\end{tabular}

\begin{tabular}{|c|c|}
\hline $\begin{array}{lr}\text { jelas. Penyampaian } \\
\text { laporan } & \text { lambat } \\
\text { karena harus } \\
\text { merekap satu per } \\
\text { satu data di kertas. }\end{array}$ & \\
\hline $\begin{array}{lr}\text { Pada sistem lama } \\
\text { biaya } & \text { yang } \\
\text { dikeluarkan besar } \\
\text { untuk pengadaan } \\
\text { kertas/map rekam } \\
\text { medis dan rak rekam }\end{array}$ & $\begin{array}{l}\text { Pada sistem yang baru } \\
\text { juga akan memakan } \\
\text { biaya yang besar di } \\
\text { awal, karena harus } \\
\text { memmbeli server dan } \\
\text { jaringan yang mahal }\end{array}$ \\
\hline $\begin{array}{lr}\begin{array}{l}\text { medis } \\
\text { memakan }\end{array} & \text { banyak } \\
\text { ruang } & \end{array}$ & \\
\hline $\begin{array}{l}\text { Sistem yang lama } \\
\text { masih memerlukan } \\
\text { pengendalian yaitu }\end{array}$ & $\begin{array}{l}\text { Sistem yang baru akan } \\
\text { memudahkan } \\
\text { pengendalian sehingga }\end{array}$ \\
\hline \begin{tabular}{lr}
\multicolumn{2}{l}{ keamanan data yang } \\
masih & kurang, \\
orang-orang & masih \\
bisa masuk & untuk \\
mencari & rekam \\
medis pasien &
\end{tabular} & kemanan bisa terjaga \\
\hline $\begin{array}{l}\text { Sistem yang lama } \\
\text { tidak efisien karena } \\
\text { harus memindahkan } \\
\text { rekam medis dari } \\
\text { ruang rekam medis } \\
\text { ke poliklinik tujuan } \\
\text { pasien }\end{array}$ & $\begin{array}{l}\text { Sistem yang baru akan } \\
\text { membuat data rekam } \\
\text { medis pasien langsung } \\
\text { menuju ke poliklinik } \\
\text { tujuan setelah } \\
\text { pendaftaran }\end{array}$ \\
\hline $\begin{array}{l}\text { Sistem yang lama } \\
\text { membutuhkan waktu } \\
\text { yang lama untuk } \\
\text { melayani pasien, } \\
\text { mulai rari } \\
\text { pengambilan antrian } \\
\text { hingga pemberian } \\
\text { obat. Karena masih } \\
\text { banyak kegiatan } \\
\text { catat mencatat, dan } \\
\text { pencarian rekam } \\
\text { medis yang tidak } \\
\text { ditemukan karena } \\
\text { pasien tidak } \\
\text { membawa kartu } \\
\text { rekam medis }\end{array}$ & $\begin{array}{l}\text { Sistem yang baru akan } \\
\text { waktu tunggu pasien, } \\
\text { karena mulai dari } \\
\text { pendaftaran sudah } \\
\text { tersistem, sehingga } \\
\text { bisa langsung masuk } \\
\text { ke pemeriksaan dan } \\
\text { kegiatan pencarian } \\
\text { rekam medis akan } \\
\text { dihilangkan, karena } \\
\text { sudah tersistem }\end{array}$ \\
\hline
\end{tabular}

b. Matriks SWOT

Tabel 2.

Matriks SWOT

\begin{tabular}{llll}
\hline \hline \multicolumn{1}{c}{ S (Strength) } & W (Weakness) & O (Opportunity) & \multicolumn{1}{c}{ T (Threats) } \\
- Memiliki fitur & - Pengaturan & - Perkembangan & - Pemahaman \\
yang lengkap & penggunaan & teknologi & mengenai \\
- Dapat diakses & yang rumit & - Meningkatkan & penggunaan \\
dengan mudah & - Biaya & produktivitas & teknologi yang \\
- Keamanan & pengadaan & Puskesmas & minim \\
terjaga & hardware dan & - Mempermudah & - Terganggunya \\
- Terintegrasi & software yang & dan mempercepat & perangkat \\
dengan beberapa & mahal & kinerja karyawan & hardware/softw \\
sub unit & - SDM yang & & are \\
& kurang menguasi & & \\
& teknologi & & \\
\hline
\end{tabular}




\begin{tabular}{llll}
\hline SO (Strength \& & ST (Strength \& & WO (Weakness \& & WT (Weakness \\
Opportunity) & \multicolumn{1}{c}{ Threats) } & $\begin{array}{c}\text { Opportunity) } \\
\text { \& Threats) }\end{array}$ \\
Memanfaatkan & Menciptakan & Menciptakan & Meminimalisir \\
teknologi untuk & keunggulan & keunggulan yakni & kesalahan \\
mempercepat & kompetitif & penggunaan sistem & pencarian rekam \\
kinerja & dengan & informasi rekam & medis dan \\
karyawan & Puskesmas lain & medis sendiri & transfer rekam \\
& & & medis antar sub \\
& & & unit \\
\hline \hline
\end{tabular}

2) Analisis Sistem Usulan

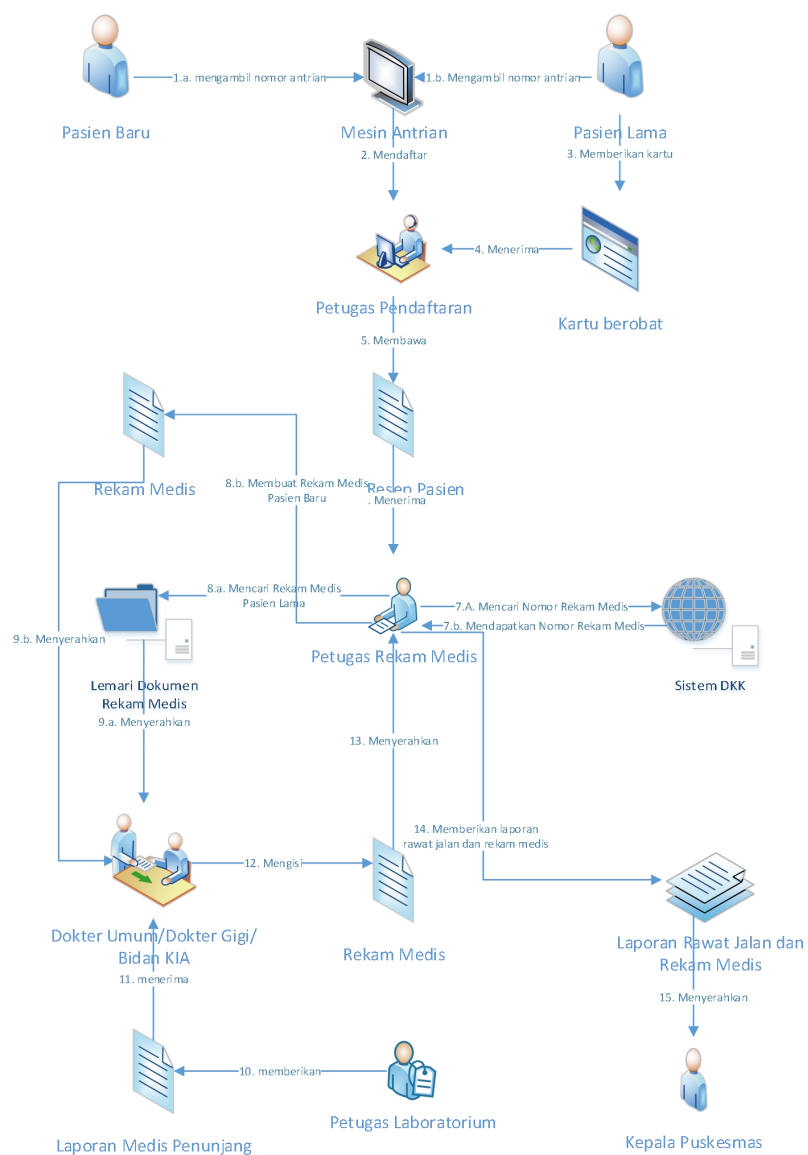

Gambar 3. Sistem Usulan

Selanjutnya setelah didapati sistem berjalan, maka dibuatlah sistem usulan sistem yang digunakan. Usulan sistem ini digunakan untuk mendesain sistem informasi rekam medis yang akan dibuat. Sistem usulan ini dibuat berdasarkan analisis sistem berjalan dengan fakta di lapangan.

\section{B. Workshop Design \\ 1) Perancangan Proses}
a. Use Case Diagram

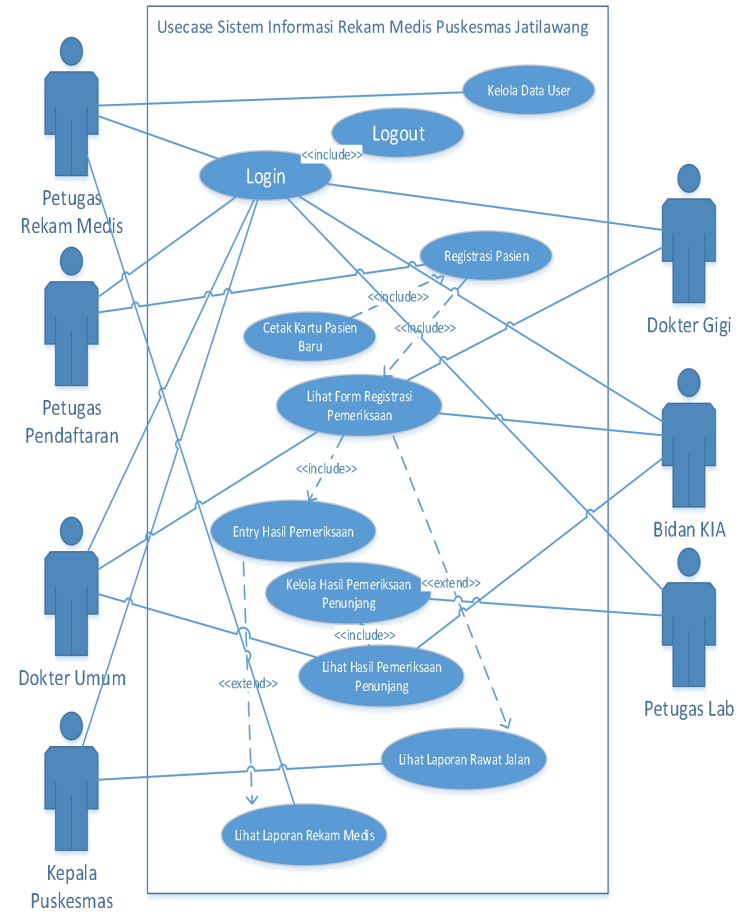

Gambar 4. Use Case Diagram

\section{b. Activity Diagram}

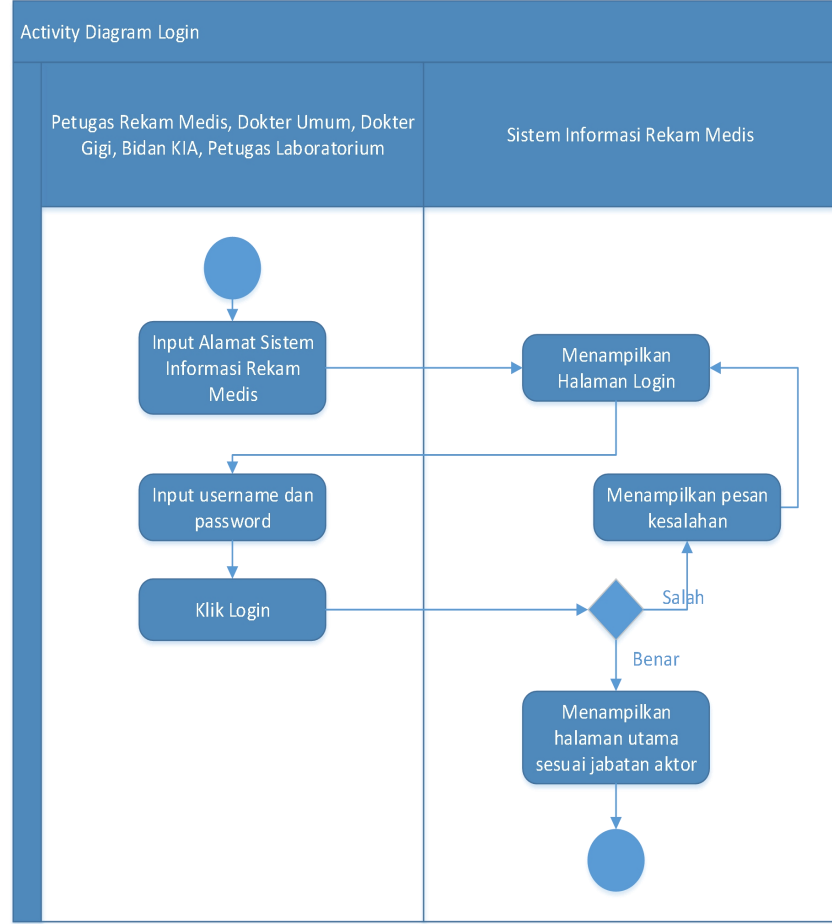

Gambar 5. Activity Diagram Login 
Applied Information Systems and Management (AISM)

Volume 2, (1) 2019, hal 40-46

P-ISSN: 2621-2536; E-ISSN: 2621-2544

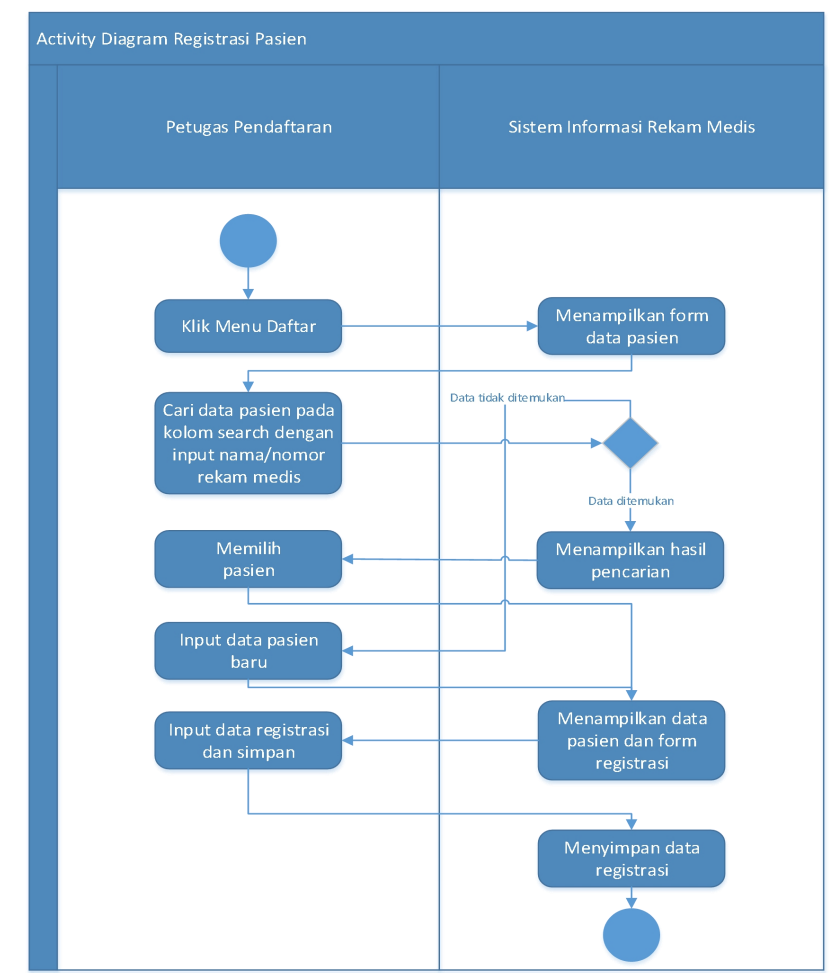

Gambar 6. Activity Diagram Registrasi Pasien

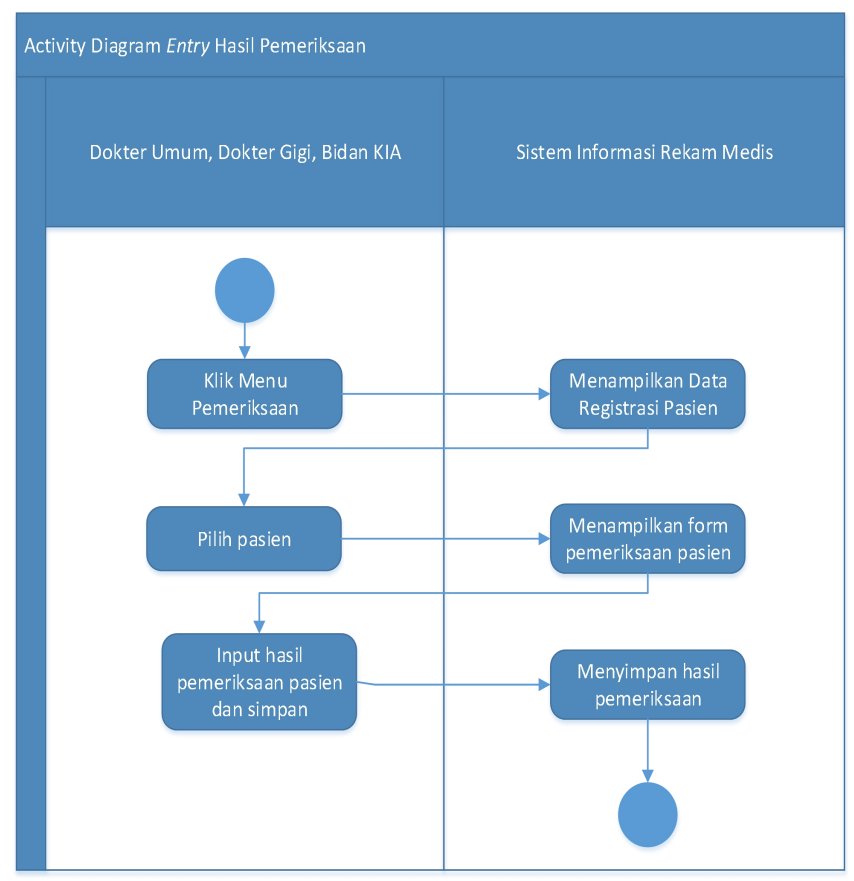

Gambar 7. Activity Diagram Entry Hasil Pemeriksaan

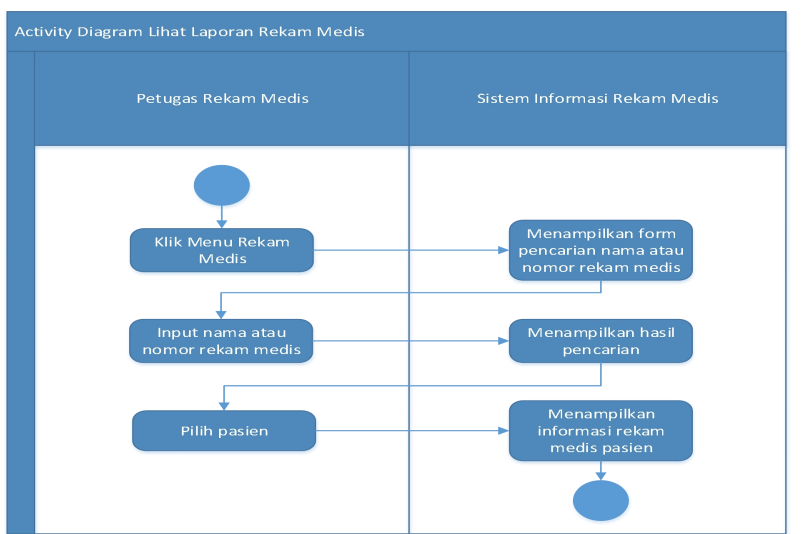

Gambar 8. Activity Diagram Lihat Laporan Rekam Medis

2) Perancangan Database

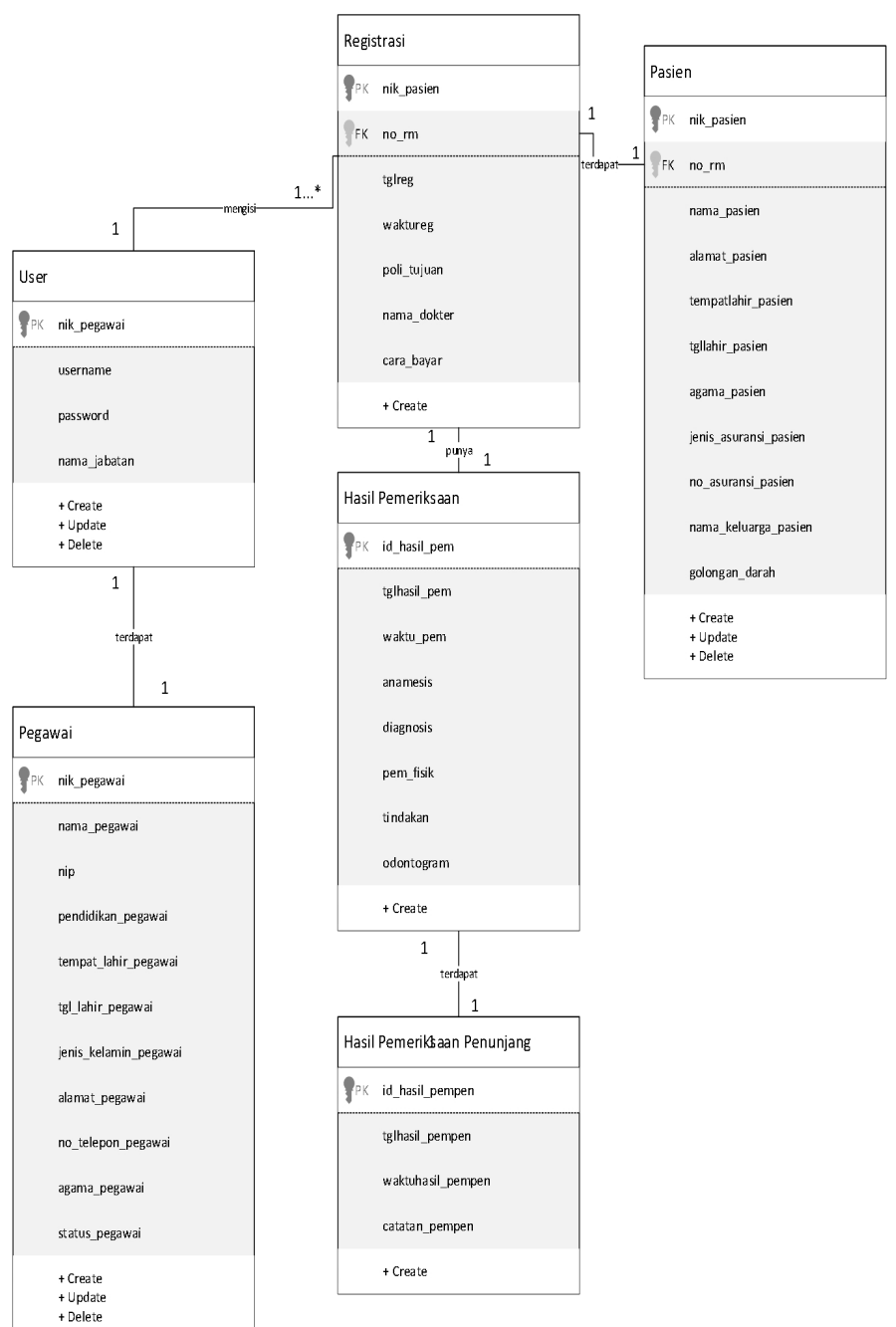

Gambar 9. Class Diagram Sistem Informasi Rekam Medis Puskesmas 
3) Perancangan Interface

Ilustrasi desain interface sistem ini tercantum pada Gambar 10 hingga Gambar 14.

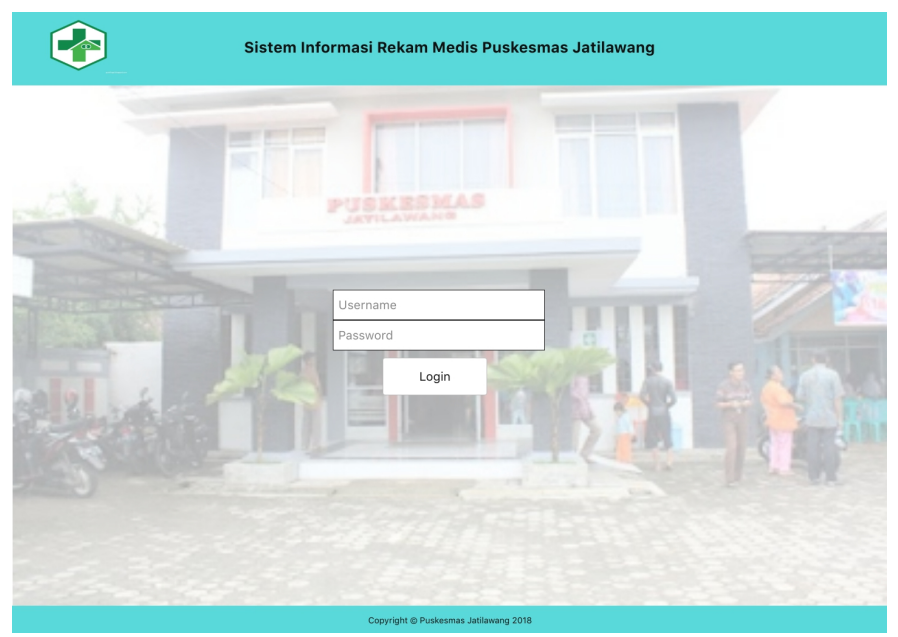

Gambar 10. Desain Interface Login

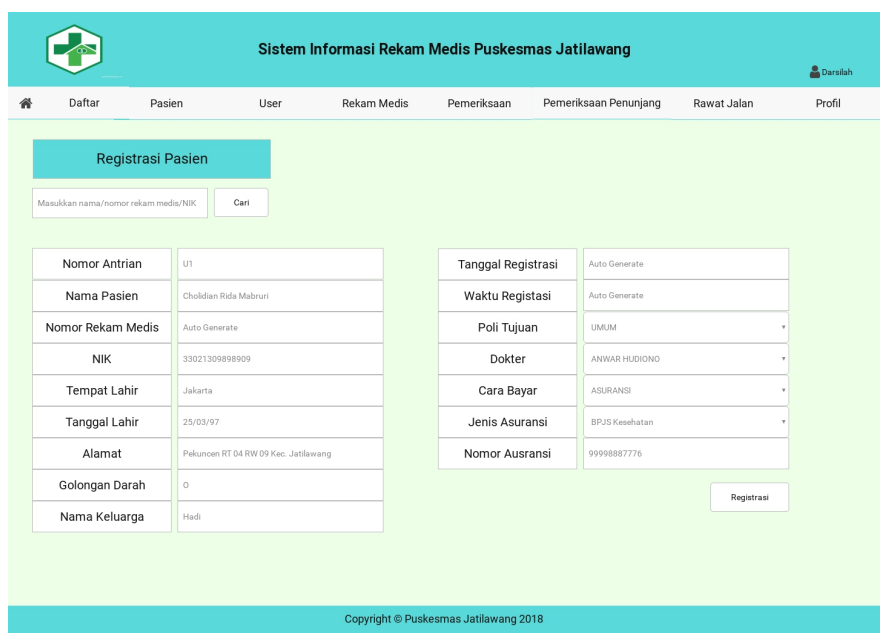

Gambar 11. Desain Interface Registrasi Pasien Baru

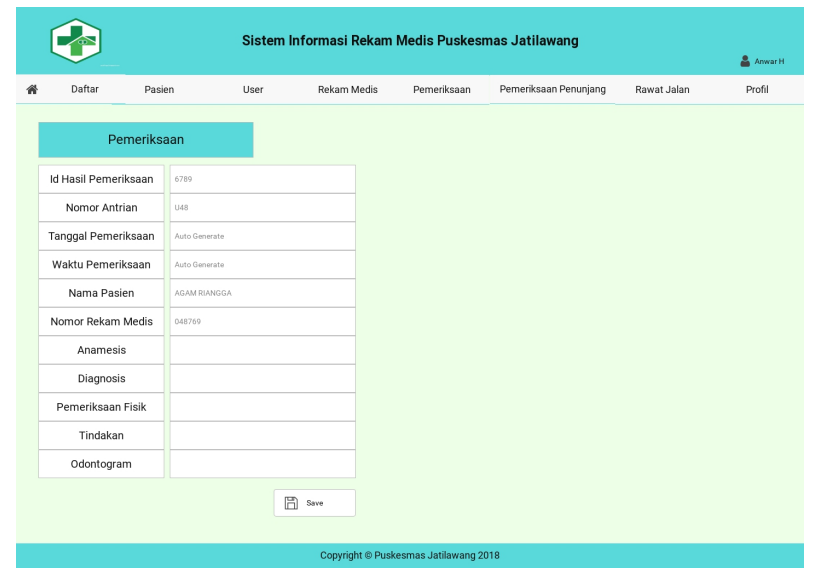

Gambar 12. Desain Interface Entry

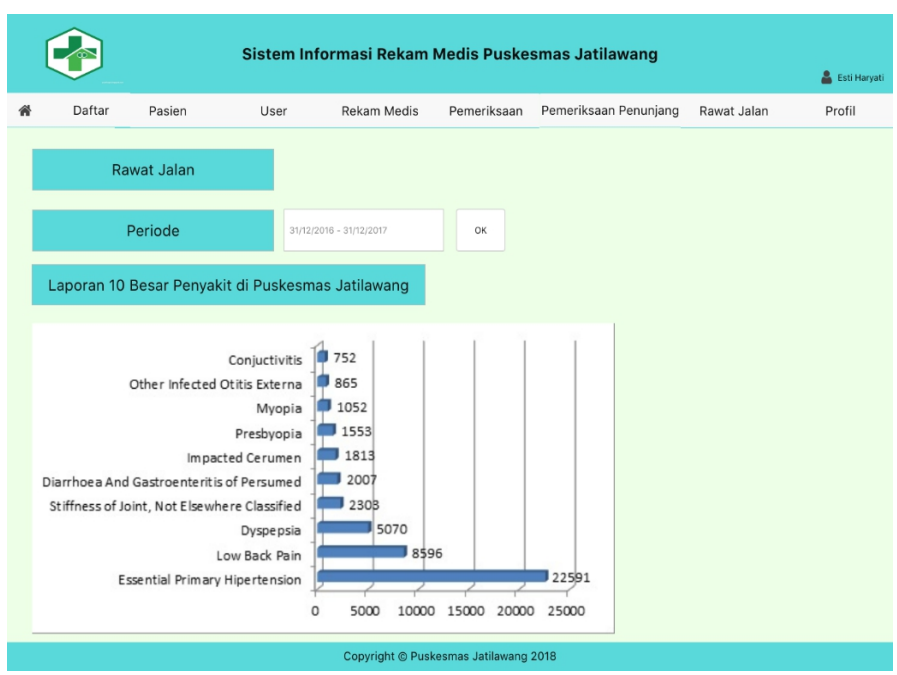

Gambar 13. Desain Interface Laporan Rawat Jalan Pasien

\begin{tabular}{|c|c|c|c|c|c|}
\hline \multirow[b]{2}{*}{ 䑩 } & \multirow[b]{2}{*}{ Pasien } & \multicolumn{2}{|c|}{ Sistem Informasi Rekam Medis Puskesmas Jatilawang } & \multirow{2}{*}{\multicolumn{2}{|c|}{$\begin{array}{l}2 \text { Feri Astut } \\
\text { Profil }\end{array}$}} \\
\hline & & Rekam Medis & Pemeriksaan $\quad$ Pemeriksaan Penunjang & & \\
\hline \multicolumn{6}{|c|}{ Rekam Medis } \\
\hline \multicolumn{2}{|c|}{ Masukhan rama/namor rekan reats/NK } & cari & & & \\
\hline No & Nomor Rekam Medis & Nama & Alamat & Nama Keluarga & \\
\hline 1 & 000001 & Restriana Hadi Oktalasa & PEKUNCEN $1 / 4$ KEC. JATLLAWANG & REZKY & \\
\hline 2 & 000002 & Dwi Adji Prasetyo & BANTAR 2/4 KEC. JATILAWANG & ADITIA & \\
\hline 3 & 000003 & Firna Helfira & KARANGANYAR $1 / 3$ KEC. JATILAWANG & IBRAHIM & \\
\hline 4 & 000004 & Aliya Huzna Vania & PEKUNCEN 3/4 KEC. JATLAWANG & HASAN & \\
\hline 5 & 000005 & Ferdian Rachardi & PEKUNCEN 3/4 KEC. JATLAWANG & DILAN & \\
\hline 6 & 000006 & Wildan Satrio Utomo & PEKUNCEN 7/4 KEC. JATLLAWANG & MILEA & \\
\hline 7 & 000007 & Maya Agustina Waluyo & GUNUNGWETAN 1/4 KEC. JATLLAWANG & WALUYO & \\
\hline 8 & 000008 & Ulyatin Tidhomah Jamil & TUNJUNG 10/4 KEC. JATLLAWANG & JEFRI & \\
\hline 9 & 000009 & Alfi Rizalul Awwal & PEKUNCEN 1/4 KEC. JATILAWANG & PUTRA & \\
\hline 10 & 000010 & Rahmadi Prabowo & PEKUNCEN $1 / 4$ KEC. JATLANANG & KASIM & \\
\hline
\end{tabular}

Gambar 14. Desain Interface Laporan Rekam Medis Pasien

\section{KeSIMPULAN}

Berdasarkan pembahasan diatas didapatkan bahwa sistem informasi rekam medis puskesmas Jatilawang mudah untuk ditransfer antar poli dikarenakan antar poli sudah saling terhubung. Dengan menggunakan fitur pencarian rekam medis pasien, data rekam medis pasien mudah ditemukan. Dalam sistem informasi rekam medis ini, semua aspek saling terhubung mulai dari pendaftaran, poli umum, poli gigi, poli KIA, laboratorium, dan rekam medis. Analisis dan perancangan sistem informasi rekam medis pada Puskesmas Jatilawang untuk mempermudah dan mempercepat proses rekam medis pasien sehingga menghasilkan informasi rekam medis pasien yang akurat, cepat, dan efisien.

\section{REFERENSI}

[1] Kementerian Kesehatan Republik Indonesia, "Peraturan Menteri Kesehatan Nomor 75 Tahun 2014 Tentang Pusat Kesehatan Masyarakat,"

http://www.depkes.go.id/resources/../peraturan/PMK-No-75-Th-2014-t 
tg-Puskesmas.pdf diunduh pada tanggal 21 Desember 2017 pukul 14.00 WIB.

[2] Kementerian Kesehatan Republik Indonesia, "Peraturan Menteri Kesehatan Republik Indonesia Nomor 97 Tahun 2015 Tentang Peta Jalan Sistem Informasi Kesehatan Tahun 2015-2019," http://www.pusdatin.kemkes.go.id/resources/download/pusdatin/lain-lai n/PMK-No-97-Th-2015-ttg-Peta-Jalan-Sistem-Informasi-Kesehatan-Ta hun-2015-2019.pdf diunduh pada tanggal 21 Desember 2017 pukul 14.10 WIB.

[3] H. E. Shortliffe, Medical Informatics: Computer Applications in Health. New York: Springer, 2001.

[4] T. H. Payne, Practical Guide To Clinical Computing System. University of Washington, Seattle Elsevier: First Edition, 2008.

[5] G. Susanto and Sukadi, "Sistem Informasi Rekam Medis Pada Rumah Sakit Umum Daerah (RSUD) Pacitan Berbasis Web Base," J. SpeedSentra Penelit. Eng. dan Edukasi, vol. 9, no. 3, pp. 18-24, 2011.

[6] V. Widowati, "Pengaruh Kecepatan Pemberkasan Rekam Medis Elektronik dan Rekam Medis Manual Rawat Jalan Terhadap Ketepatan Waktu Pengumpulan Berkas JKN di Klinik Interne RS Bethesda." Fakultas Ilmu Kesehatan Universitas Muhammadiyah Surakarta,
Surakarta, http://eprints.ums.ac.id/33481/\%0A diunduh pada 21 Desember 2017 pukul 20.00 WIB.

[7] H. Yonathan, "Perbedaan Rekam Medis Manual dan Rekam Medis Elektronik," Semarang, https://www.slideshare.net/FitriRiyanto/tesis-rm diunduh pada tanggal 21 Desember 2017 pukul 20.30 WIB. .

[8] G. Hatta, Manajemen Informasi Kesehatan. Jakarta: UI Press, 2008.

[9] J. Hutahaean, Konsep Sistem Informasi, 1st ed. Yogyakarta: Deepublish, 2014.

[10] Kementerian Kesehatan Republik Indonesia, "Peraturan Menteri Kesehatan Republik Indonesia Nomor 269 Tahun 2008," Jakarta, 2008 http://dinkes.surabaya.go.id/portal/files/permenkes/dok_dinkes_87.pdf \%0A diunduh pada tanggal 21 Desember 2017 pukul $14.00 \mathrm{WIB}$.

[11] M. Leod and J. R., System Development: A Project Management Approach. New York: Leigh Publishing LLC, 2009.

[12] J. L. Whitten and L. D. Bentley, System Analysis \& Design Methods: Sixth Edition. New York: Mc.Graw-Hill, 2004.

[13] D. M. Kroenke, Database Processing Dasar-Dasar, Desain \& Implementasi. Jakarta: Penerbit Erlangga, 2005. 